\title{
Meanings and Values of Local Wisdom in Sura Salvation Ceremony of Samin Jepang Community, Indonesia for Audio Visual Technology-Based Learning
}

\author{
${ }^{1}$ Nur Alfin Hidayati, ${ }^{2}$ Herman J. Waluyo, ${ }^{3}$ Retno Winarni, ${ }^{4}$ Suyitno \\ ${ }^{1}$ nikidanajwasalsabila@ gmail.com, ${ }^{2}$ herman.jwaluyo@yahoo.co.id, ${ }^{3}$ winarniuns@yahoo.com, \\ ${ }^{4}$ yitsuyitno52@gmail.com \\ ${ }^{1}$ Sebelas Maret University, IKIP PGRI Bojonegoro \\ ${ }^{234}$ Sebelas Maret University
}

\begin{abstract}
The aim of this research is to investigate the meanings and values of local wisdom in Ritual Ceremony of Sura Salvation of Samin Jepang community, Margomulyo, Bojonegoro Regency, East Java, Indonesia for audio visual technology-based learning. Descriptive-analytic method by interpretative approach was employed in this research. The data sources were sesepuh (parents), pinisepuh (old people), head of village, Samin community, Samin leader, activities pre-and-post ritual ceremony of Sura salvation. Data were collected through documentation, observation, and in-depth interview and analyzed inductively. The researcher herself became the research instrument supported by recording device and camera. The data validity was examined by triangulation of source and method. The recorded video containing local wisdom of Samin community was then used to implant character education in teaching literary appreciation. Video as the audio visual medium can attract and engage the students' attentions, feelings, and thoughts on Sura salvation ceremony. The results of research were as follows: (1) ritual ceremony of Sura salvation serves as means of thanksgiving to God and praying for safety from all disasters; (2) the local wisdoms of ritual ceremony of Sura salvation are discussion to have communal decision, fortune sharing, cooperation, responsibility, believe in God, and pray for safety; (3) video of Sura salvation ceremony as audio visual aid can be used to implant local wisdom as character education in teaching literary appreciation. Through this video delivered in recreational, responsive, and redescriptive learning model, the students could understand, find, enjoy, and appreciate the meanings of Sura salvation ceremony; they analyzed and gave responses on this ceremony and life reality; they described again the elements of culture and literature by their own words.
\end{abstract}

Keywords: Meaning, Ritual, Local Wisdom, Sura, Samin, audio visual

\section{Introduction}

Society and culture has reciprocal relationship[1]. The diversity of people influences the diversity of cultures in certain communities and vice versa. In fact, many traditional cultures of Javanese community which are full of meanings, values, and indigenous element are wear-off and disappeared even extinct due to external culture[2]. A study on educational value of traditional culture must be developed. People must appreciate it to conserve cultural heritage. Traditional culture shows the authenticity of culture in certain communities. Cultural authenticity becomes the identity of people who own it. Ritual ceremony of Sura salvation is one of authentic cultures of Samin community in Jepang Hamlet, Margomulyo Village, Bojonegoro. 
Ritual ceremony of Sura salvation belongs to heritage or hereditary tradition carried out annually by Samin Jepang community which is very important and sacred[3]. This ceremony has some changes along with the development of era. However, these changes do not diminish the existing values and functions. It is expected that these values will be kept and preserved. The ceremony is conducted solemnly every year by Samin community.

Sura salvation ceremony is used as a means of praying to God for safety and calm[4]. It actualizes the honor to Dhanyang or God for his protection. Generally, the sequence of this traditional ceremony is intended for keeping the balance between human and unseen thing. The harmonious condition will bring to safety, peace, and convenience to the community. However, to young generation, the ritual ceremony of Sura salvation only becomes annual routine which is meaningless. For this reason, a study on the values of Samin local wisdom in the ritual ceremony of Sura salvation is very important since it symbolizes the cultural authenticity of Samin community.

Although Samin Community belongs to traditional culture and far from modern culture, the local wisdom from this community can be used to teach character education to students particularly for higher education. Through recorded video, students can watch and listen to Sura salvation ceremony. They can learn about behavior and statement of Samin people in interesting and interactive ways, making abstract ideas more concrete. The importance of audio visual (AV) technology in education should not be underestimated specifically for literary learning due to two reasons: first, learning via AV creates a stimulating and interactive environment which is more conducive to learning; second, an audio-visual aid belongs to the recent era which means that having the skills to use AV equipment is integral to future employment prospects especially as educators. Therefore, exposure to use AV technology in education is imperative. AV can be used as a medium to instill knowledge and character of students in literary learning.

\section{Literature Review}

Culture is the results of whole ideas and creations of humans that must be habituated through learning [1]. Culture covers language, social order, occupation, knowledge, technology, and religion. The cultural system becomes the principle, motivation, and monitor to all attitudes, behaviors, and actions of community which regulates social institution [5]. The ritual ceremony of Samin community, in Jepang Hamlet, Margomulyo Village, Bojonegoro belongs to the local tradition. This ritual is named Sura ceremony as it is conducted in Sura month based on Javanese calendar. According to Hijriyah calendar, then its name is Muharraman tradition or ritual. Sura salvation is a tradition resulted from the assimilation process between Javanese and Islamic cultures [3].

Ceremony (according to custom) is a thing done based on tradition or religion [2]. It is an integral part of community culture. Its preservation is strongly related to its function in community life. This ceremony will be extinct if it does not have any functions at all. Traditional ceremony has four functions to its community as follows: (1) social norm; (2) social control; (3) social media; and (4) social grouping[6]. Ceremony becomes an important event. The system of religious ceremony contains four vital aspects: (a) ceremonial place, (b) ceremonial process, (c) ceremonial equipment, and (d) people conducting and leading the ceremony. Ceremony has four elements: (1) offerings, (2) praying, (3) victimizing, (4) feast sacred by pray, (5) sacred dancing, (6) holy song, (7) carnival, (8) sacred drama, (9) fasting, (10) intoxication/blurring the thoughts by anesthetic drug to get trance/drunk, (11) meditation, (12) contemplation[1]. 
According to [2], traditional ceremony is one of cultural heritage performances. Culture is social heritage owned by certain communities through learning. Learning culture means learning mechanism or certain ways containing the norms and life values of local environment by obeying and honoring them for the sake of life continuity. Traditional ceremony is a ritual activity mass safety[7]. Traditional ceremony becomes an integral part of community culture and its preservation is determined by its function in life. It strengthens cultural norms and values symbolically. By doing traditional ceremony, the community will feel safe as it becomes the life principle of attitude and behavior. Salvation is having feast which has been prayed and it is closely related to the belief in God to get life safety and to hinder disturbances and disasters[8]. It is the actualization of Javanese people religiosity which is conducted simultaneously with neighbors, families, relatives, and friends[9].

Local wisdom of Javanese culture belongs to elements of intelligence and policy resulted from Javanese community[10]. Values are related to culture as it owns values which are inherited, interpreted, and conducted along with the process of community alteration[11].

Video as audio visual aid can be used as a medium in teaching and learning literature appreciation. According to Yunus, the benefits audio visual aid are: firstly, using visual aids in teaching literature creates strong engagement between students and the context in interesting way. It can help students to understand the abstract ideas through authentic communication. Secondly, students will be more motivated in learning literature. The students will have interest in learning literature and positive attitude towards the implementation of literature in life reality. Thirdly, the use of visual aids in literature teaching helps students to comprehend with literary and cultural concepts. The characteristics of the visual aids like sound, light and color can trigger and stimulate students' understanding.

\section{Material \& Methodology}

This researcher employed descriptive-analytic method by interpretative approach. The data sources included sesepuh, pinisepuh, Samin community, head of village, Samin leader, and activities pre-and-post ritual ceremony of Sura salvation. This research was conducted at Jepang Hamlet, Margomulyo Village, Margomulyo District, Bojonegoro Regency. The series of activities in ceremony carnival consist of two events i.e. (1) preparation involving (a) preparation of ceremonial place and (b) offerings creation; (2) implementation involving (a) opening, (b) salvation or thanksgiving, (c) praying, (d) closing by feast. Data were collected through documentation, observation, and in-depth interview. The researcher herself became the research instrument by using recorder and camera. The data were analyzed inductively. To examine the data validity, triangulations of source and method were used. Related to teaching literary to higher education students, the recorded video about Samin community can be used to teach literary appreciation particularly engaging it with character education. Through responsive, recreational, and redescriptive learning model, the video of Samin community can be used as a learning medium to teach six local wisdom (discussion, fortune sharing, cooperation, responsibility, and thanksgiving to God) to educate students' characters.

\section{Results and Discussion}

\subsection{The Meanings of Ritual Ceremony of Sura Salvation}

Ritual Ceremony of Sura salvation in Samin community uses many symbols. Offerings in this ceremony function as the media for people to get their dream/goal coming true. The ceremonial forms and equipment (ubarampe) symbolize many things. The forms 
and contents of ritual offerings in Sura salvation display typical and unique features. Samin people dominate the situation as well as geographical and anthropological conditions. Basically, the ritual ceremony of Sura salvation is almost the same as other Javanese ceremonies in terms of their equipment. Basic equipment for salvation ceremony are red and white porridges, rice cone- 'kuluban' (steamed vegetable mixed with grated coconut), and side dishes such as 'ingkung' (roasted chicken which is divided in two parts and pulls them to right and left). The other dishes are fruits (two bunches of king bananas), cakes sold in the market (small cakes), coffee, and tea. In reality, each region has different variations of ceremonial offerings depending on the tradition and the local sub-culture.

Red and white porridges symbolize the elements of mother and father. Rice cone and vegetables symbolize existence or 'jagad kang gumelar' (the world and its contents). 'Ingkung' represents 'rajakaya' (livestocks) or wealth. The essence of salvation ceremony equipment is describing the human nuance in the world and 'sangkan paraning dumadi' (the essentials of where we are from and we are going to go to).

The first and main element in this ceremony is the red and white porridges which symbolize parents as the 'lantaran' (media) of humans and life in the world. Parents and even the ancestors must be obeyed and prayed. The second element is the tumpêng and kuluban reminding us about the world and its contents exactly test reminding us on life problems. A person must be able to behave like a mountain which is strong upon typhoon, disaster, hot, rain, and flood. Mountain stays tough and stable in its place. Humans must have life principles and put them in the perspective of mountain (cone). Having strong and good personality as well as cone life goal or heading to God are the other life principles. Side dishes of meat describe the willingness to share with others (shadaqah or infaq in Islamic terms) upon the people's wealth in the world.

Samin Jepang community still uses salvation equipment but it is not standardized. It does not need to follow certain rules. The indigenous leader of Samin Jepang namely mbah (Grandpa) Hardjo Kardi, as the representation of Samin jepang culture, has stated this simplicity. The equipment of ceremony is flexible so that it does not become the burden of Samin community. This flexibility is based on the insight that the essence of salvation ritual is not on its equipment but on the intention and willingness to thank to God. To mbah Hardjo Kardi, simplicity and flexibility become the basic principles of Sura salvation ceremony. He stated to the researcher: "menawi entêné namung kulupan, nggih niku mawon, mbotên menopo" (if there is only boiled vegetables, they are permitted). In this context, the indigeneous leader of Samin community uses practical-pragmatic approach.

The 'ubarampé' for Sura salvation ceremony in 2017 is relatively simple consisting of rice cone, 'inkung' chicken, market cakes, kulupan vegetables, crackers, red and white porridges, jug water, 'sêtangkêp' (two bunches of bananas), and two glasses of milk. 'Ubarampé' of Sura salvation in Samin community is simpler than other Javanese salvation ceremonies such as 'malêman'/every odd night at the last ten days of ramadhan month to Solo people and surrounding). Simple offerings in Sura salvation reflect the simple life of Samin community. Perhaps, it will be different if Sura ceremony is carried out by the head of Regency or District. Who have tough financial support.

\subsection{The Values of Local Wisdom in Ritual Ceremony of Sura Salvation}

The conduct of ritual ceremony of Sura salvation involves many participants since the beginning to the last. They are the community of Jepang Hamlet, Margomulyo Village, Margomulyo District, Bojonegoro regency. The procession consists of sequential series of events containing policies to better conditions as follows: (1) reparation, involving (a) meeting 
of villagers, (b) preparation of ceremonial place, (c) preparation of offerings; (2) implementation, involving (a) carnival, (b) thanksgiving and praying; (3) closing, involving fighting rice cone, eating together, performing traditional art such as tayub (Javanese dance) or puppet. The activities in ritual ceremony of Sura salvation contain local wisdom values as follows:

(1) Discussion

Discussion is a routine activity that guarantees the continuity of any activities. Ritual ceremony of Sura salvation in Samin community at Jepang Hamlet, Margomulyo Village, Margomulyo District, Bojonegoro Regency. Village discussion gives positive effects to communal life in society. Through discussion, togetherness, harmony, and kinship can be created.

(2) Fortune sharing

Fortune sharing is the real actualization of social education. Through this activity, human will realize that he cannot live alone and needs the help from others. The velue of social education can be seen from the series of ceremony starting from the offerings, art performance, and wayangan (puppet show). People of Jepang Hamlet do the ceremony sincerely by donating money, things, harvest production, and ability in art work to entertain the community. Some people bring ketupats (diamond-shaped of woven young coconut leaf steamed rice) as offerings. These ketupats are then distributed to many people. The other social education can also be noticed from wayangan. People can enjoy the food freely while watching wayang show played by a dalang (puppet player). Besides, as a religious human who believes that humans are living tohether with unseen creatures, the burn of kemenyan (olibanum) in ceremonial offerings is the actualization of fortune sharing with other God creatures.

(3) Cooperation

Samin community in Jepang Hamlet, Margomulyo Village, Margomulyo District, Bojonegoro Regency upholds ancestor tradition. Cooperation belongs to one of its traditions. Samin community conducts Sura salvation ceremony by cooperating one to another from the preparation to the finishing processes.

(4) Responsibility

Responsible attitude is part of virtues. Somebody is stated to have good behavior and morality will not ignore his duty and responsibility. Responsibility can be seen from the conduct of haul (spirit salvation) as tradition ceremony. People make a small committee who has different duties and responsibilities. This ceremony educates people to have spirit of learning and implant responsibility to young generation. Moreover, the women take a part in cooking and preparing ubarampe (everything) that is used in the carnival and offerings in Sura ceremony. Educating virtues can also be noticed from the art performance, tahlil (Islamic sentence and salvation ceremony), offerings, and puppet show. The activeness and orderliness of Samin community to support Sura ceremony shows their responsibilities. They become aware of others and do the best for their community.

(5) Thanksgiving to God

Carnival belongs to thanksgiving to God in terms of offerings. Samin people thank to God because their desires (nadar or promise before the dream comes true) can be achieved. They hold carnival to celebrate their nadar. Samin people believe that their intention will not be acceptable if they do not do carnival and salvation in Sendhang Suruh. Thus, they will not break their promises. According to Purwadi (2005), salvation 
is compulsory requirement and must not be disobeyed if someone does not want to get accident or unblessing life. Thanksgiving to God belongs to local wisdom value. The carnival ceremony of Sedekah Pasrah at Sendhang Suruh, Giri Tengah Village also provides the local wisdom by people's obedience to custom rules. During the salvation procession, people firstly have to get permit to Dhanyang (the keeper) of Sendhang Suruh so that he will not disturb the villagers. Praying together shows that Samin community thanks to God.

\subsection{Samin Ceremony to Teach Literary Appreciation}

Ritual ceremony is cultural ritual which has spiritual dimension. Salvation ceremony is deep-rooted behavior in traditional Javanese community such as Samin Jepang community, in Margomulyo, Bojonegoro. Salvation becomes the actualization of religiosity of Javanese people.it is the practice of feast by meeting neighbors, families, relatives, and friends[9]. Ritual ceremony of Sura salvation becomes the medium to communicate and pray to the almighty God to get his bless and happy life. If somebody/group/community wants to celebrate or make sacred events related to personal ceremony or if somebody/group/community asks for fortune or protection from disaster, then salvation must be conducted[12]; [1]. Samin Jepang community in Margomulyo, Bojonegoro employs ritual ceremony of Sura salvation as a means of thanksgiving to God.for everything he has given as well as a means of pray to get safety from disaster.

Values are related to culture as it has hereditary values which are inherited, interpreted, and conducted along with the process of community alteration[11]. The ritual ceremony of Sura salvation in Samin community has cultural values which have been inherited and conducted by some generations. It becomes the heritage of ancestor which is still maintained by Samin Jepan community in Margomulyo, Bojonegoro. It is a culture resulted from humans creation to develop their attitudes toward the life which is inherited from one generation to the next one through communication and learning processes so that the newest generation has tough characters in undergoing the life [13].

Literary appreciation is very vital to students as it attempts to develop feeling, creation, and willingness. The main function of literary is to smooth moral, improve humanity and social care, grow cultural appreciation, and deliver ideas, imagination, and expression creatively and constructively. Meeker[14] states that as imaginary creation, literature becomes the construction of life experience which correlates relationship between humans and nature, so that it can influence humans' responses.

Wisdom is a policy, while Samin is a community. Local wisdom of Samin community means the local idea which becomes a policy and is full of virtue and good value, implanted and followed by the community members. Local wisdom of Samin community contains virtues such as discussion, fortune sharing, cooperation, responsibility, and thanksgiving to God. These virtues have existed from many years ago to the recent modern era. What perception Samin people hold, how they react the modern era, how they behave to keep good relationship with among humans, nature, and God are materials than can be taught to student in relation to literary appreciation

\subsection{Implanting Local Wisdom of Samin Community to Teach Character Education through Audio Visual Technology}

The video of Samin community in conducting Sura salvation ceremony can be used as a material to implant character education to higher education students. This 30 minutes video presents the process of ritual Sura salvation ceremony starting from the preparation, whilst- 
activity, till the end. All of them contain and emphasize its local wisdom. During the preparation, they have discussion first to build committee of ceremony; in the whilst-activity, they cooperate with each other to prepare uborampe, stage, and entertainment; at the end, all Samin people feel and honour this ceremony as a medium to have good relationship with humans, nature, and God. This video can attract and engage students on the real Javanese culture. Although Samin people have traditional culture, their local wisdom contains virtues that can be implement in this modern era.

National character development through local wisdom is very needed. Development of national character can be taken by transforming local apeic values as a means to build the nation's character through literary learning with audio-visual media (video) that is broadcasted in class. Then the local wisdom in AV media was observed and analyzed by students as they were more real as a reinforcement of the nation's character. The video of Samin community belongs to one of means to build the nation's character which can be carried out by transforming the values of local wisdom, namely the culture of discussion, fortune sharing, mutual cooperation, responsibility, and thanksgiving to God. Sura salvation ceremony held by Samin community becomes the public interest and this community has social solidarity to conduct it.

\section{Conclusion}

Ritual ceremony of Sura salvation means the tradition given to respect and praise to God for his fortune. It functions as a medium of praying to get better fortune. The values of local wisdom in this ceremony include discussion to get communal decision, fortune sharing, cooperation, believe in God by praying and asking safety, and believe in unseen things. All of these are presented in attractive video so that students can listen and watch the ceremony process, engage their feelings and insights through authentic communication. The local wisdom in Sura salvation ceremony contains virtues for character education. Students can learn literary appreciation on Samin culture. Through video of this ceremony, they could understand, enjoy, find, and appreciate the meaning of Sura salvation ceremony. They analyzed and gave responses on Samin community and life reality. They also described again the elements of literature and meanings of this ceremony by their own words.

Acknowledgement.Thanks to the Minister of Research, Technology, and Higher Education who has helped financial support to this dissertation research.

\section{References}

[1] Koentjaraningrat, Pengantar Ilmu Antropologi. Jakarta: Rineka Cipta, 2000.

[2] Purwadi, Upacara Tradisional Jawa (Menggali Untaian Kearifan Lokal). Yogyakarta: Pustaka Pelajar, 2005.

[3] M. Sholikin, Misteri Bulan Sura Perspektif Islam Jawa. Yogyakarta: Penerbit Narasi, 2010.

[4] H. Et, Suran: Antara Kuasa Tradisi dan Ekspresi Seni. Yogyakarta: Pustaka Marwa, 2005.

[5] Nurudin, Agama Tradisional. Malang: UMM Press, 2002.

[6] W. Santosa Hendra, "Peran Wanita Dalam Seni Pertunjukan Tradisiona 1 Minangkabau Di Tengah Perubahan Kehidupan Sosio Kultural Masyarakatnya," J. Seni Pertunjuk., vol. 4, no. 1, pp. 63-70, 2018.

[7] S. R. Soeprto, Aneka Tumpeng Tradisional. Yogyakarta: Universitas Gadjah Mada, 
2008.

[8] A. Adriyanto, Pengungkapan nilai-nilai kepercayaan komunitas adat: Studi Tentang Budaya Tenggerdi Desa Ngadat. Yogyakarta: Balai Pelestarian Sejarah dan Nilai Tradisional, 2006.

[9] M. . Yana, "Tumpeng Ruwatan dan Falsafah Hidup Jawa," J. Patrawidya. Seri Pnb. Penelit. Sej. dan budaya, vol. 11, no. 3, pp. 45-57, 2011.

[10] H. Rahyono, "Euphemism in Oral Dialect Speech Ngeto-Ngete District Suralagaitle," Int. J. Linguist. Lang. Cult., vol. 3, no. 1, pp. 52-59, 2017.

[11] R. Yunus, Nilai-nilai Kearifan Lokal (Local Genius) Sebagai Penguat Karakter bangsa. Yogyakarta: CV.Budi Utomo, 2014.

[12] Z. Muchtarom, Islam Di Jawa, dalam Perspektif Santri dan Abangan. Yogyakarta: Salemba Diniyah, 2003.

[13] M. Grimmit, Religious Education and Human Development. 2010.

[14] J. W. Meeker, The Comedy of Survival: Studies in Literary Ecology. New York: Charles Schribner's Sons, 1972. 